\title{
Hniezdiace spevavce trstín a environmentálne faktory: prípadová štúdia ramena Šrek v alúviu rieky Morava
}

\author{
Breeding passerines in reeds and environmental factors: a case \\ study of Šrek oxbow in Morava River floodplain (SW Slovakia)
}

\section{Miloslav Mišík \& Emília Mišíková Elexová}

Pribišova 7,84105 Bratislava, Slovensko; e-mail: misik.milo@gmail.com,emi.elexova@gmail.com

\begin{abstract}
The relatively untouched character of the floodplain of the Morava River is related to the long-forbidden entry into the Slovak-Austrian border zone designated by this river. Since 1990 the area is reserved for nature protection. A lack of knowledge about breeding bird assemblages from this valuable area is a consequence. Nest monitoring of reed passerines, focusing on the occurrence of the bluethroat (Luscinia svecica cyanecula) was performed in April-July 2018 and 2020 in the riparian vegetation of a selected section of the Šrek oxbow. Relation of habitat and weather factors were studied in six recorded reed passerine species - Acrocephalus schoenobaenus, A. arundinaceus, A. scirpaceus, Emberiza schoeniclus, Locustella luscinioides and Luscinia svecica cyanecula. For the target criteria species the bluethroat, nesting was also proven in 2020, with estimated density of 4.7 breeding pairs 110 ha. Significant affinity for the open water was documented in A. arundinaceus, when the bluethroat preferred the points with broadleaved riparian banks.
\end{abstract}

Key words: bird assemblages, bluethroat, reed, Slovakia

\section{Úvod}

Mokrade patria k najproduktívnejším ekosystémom sveta, ktoré sú vd'aka pestrosti stanovíšt' závisiacich od prítomnosti vody, charakteristické vysokou rozmanitost'ou živočíchov a rastlín (Poulin 2002). Reguláciami tokov a ich ramien, stavbou vodných diel, alebo odvodňovaním pol'nohospodársky využívaných území sú mokrad'ové biotopy vysušované a dochádza postupne k ich zániku, v súčasnosti navyše urýchlenému vplyvom otepl'ovania klímy. Trávne ekosystémy aluviálnych (zaplavovaných) lúk sú v Európe prioritou z hl’adiska ochrany hniezdiacich druhov, s najvyšším počtom ustupujúcich a ohrozených druhov (Tomovčík 1999, Tomovčík et al. 1999). Systém riečnych mokradí Devínskeho jazera, s vlhkomilnými bylinnými biotopmi, patrí medzi najväčšie a najzachovalejšie fragmenty alúvia Moravy, s výskytom druhov viazaných na nivu rieky a jej okolité mokrad'ové biotopy. Predstavuje jedno z najzachovalejších, prirodzene každoročne zaplavovaných území v Európe (obr. 1,2). Takéto nížinné prostredie vodných plôch je pre vtáctvo vel'mi atraktívne, v stojatých vodách a na mokradiach uvádza asi 70 druhov vtákov (32\% druhov hniezdičov Slovenska; Krištín 2002). Vzhl'adom na skutočnost', že mokrade patria celosvetovo k najohrozenejším ekosystémom (Danko et al. 2002), je pre zachovanie diverzity organizmov a pre udržanie rovnováhy v krajine, takmer povinnost'ou starat' sa o takýto cenný biotop. Ekologickým vzt’ahom vtákov k biotopu 


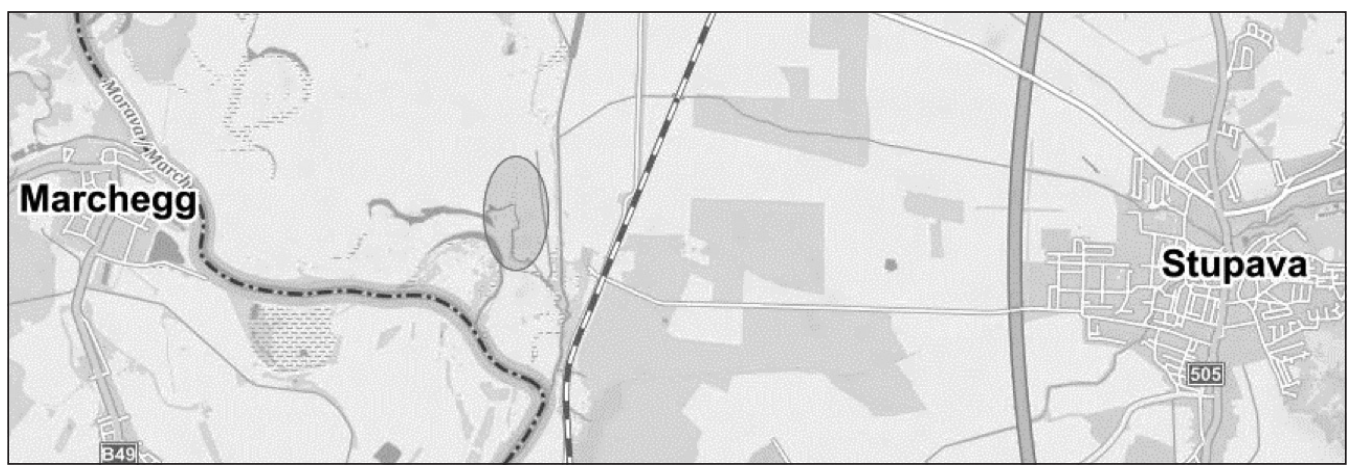

Obr. 1. Monitorovaná lokalita - Mŕtve rameno Šrek a okolité lúky nivy Moravy.

Fig. 1. Monitored site - Šrek oxbow and surrounding meadows in Morava river floodplain.

aluviálnych lúk sa intenzívnejšie venovali napr. Tomovčík (1999) a Zuna-Kratky et al. (2000), pričom najväčší podiel diverzity hniezdičov alúvia Moravy uvádzajú práve z Devínskeho jazera. Prítomnost' vzácnych a ekologicky vel'mi hodnotných trstinových habitatov podmieňuje druhovú diverzitu vtákov (Paracuellos 2006). Osobitnú čast' avifauny predmetného biotopu predstavujú trstinové druhy spevavcov, ktoré sú ideálnou skupinou pre štúdium miery ich viazanosti na rôzne typy trstinových brehových porastov ako aj na viac alebo menej otvorené vodné plochy. Ide o modelovú skupinu druhov, vhodnú pre evolučné a ekologické výskumy (Leisler et al. 1989, Hoi 2001, Báldi 2006). Zistenie miery viazanosti trstinových spevavcov na určité habitaty by mohlo pomôct' pri indikovaní stavu mokrad'ových biotopov a v prípade výraznejšej viazanosti určitého druhu možno

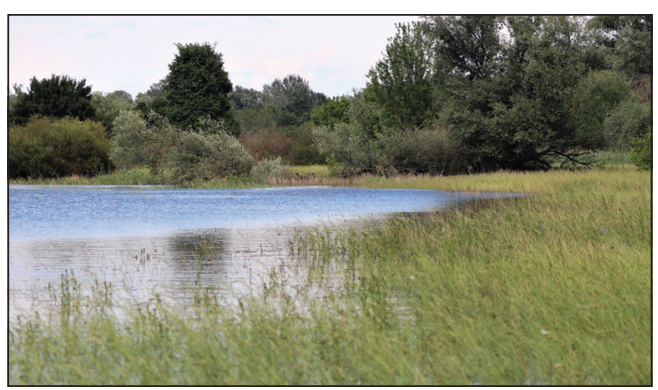

Obr. 2. Letná záplava v alúviu rieky Morava, Devínske jazero - júl 2020 (foto M. Mišík).

Fig. 2. Summer flood in Morava river floodplain, Devínske jazero lake - July 2020 (photo by M. Mišik). dokonca hovorit' o jeho indikačných vlastnostiach. Pri ochrane jednotlivých druhov považuje Báldi (2004) za dôležité zamerat' sa na ochranu ich pôvodných hniezdnych biotopov a poznat' minimálnu požadovanú rozlohu územia pre stanovenie teritória. Podl'a Zanette (2000) je dôležité pre ochranu prírody zaznamenávanie druhov citlivých na zmeny hniezdnych habitatov, ich prezencia alebo absencia indikuje stupeň pôvodnosti a kvality týchto habitatov.

Pomerne nedotknutý ráz záplavového územia rieky Morava súvisí s dlhodobým zakázaným vstupom do slovensko-rakúskeho hraničného pásma, vymedzeného touto riekou. Územie bolo častou bývalej Železnej opony počas studenej vojny. Od r. 1990 je územie vyhradené pre ochranu prírody. Dôsledkom je nedostatok poznatkov o nidocenózach $\mathrm{z}$ tohto na vtáctvo bohatého územia. Monitoring cielovej skupiny trstinových spevavcov bol preto zameraný na brehové porasty (prevažne trstiny) vybraného úseku mŕtveho ramena Šrek. Monitorované územie sa navyše vyznačuje aj výskytom populácie silne ohrozeného slávika modráka stredoeurópskeho (Luscinia svecica cyanecula), kritériového druhu pre dané CHVÚ (Demko et al. 2014, Karaska et al. 2015).

Monitoringu trstinových druhov spevavcov sa na lokalite NPR Parížske močiare venovali Trnka (2005), Trnka \& Hrdlovič (2007) a Trnka et al. (2003, 2008). Vtáctvo CHVÚ Poiplie, ktoré vzhladom na rozsiahle močaristé biotopy z velkej časti tiež zahŕňa trstinové 
spevavce, monitorovali v rozpätí rokov 1989 - 2010 Mojžiš et al. (2011). V rámci súpisu rozšírenia vtákov na Slovensku (Danko et al. 2002) sa výskytom hniezdnych lokalít slávika modráka v posledných 30 rokoch zaoberali na Parížskych močiaroch Kloubec a Čapek (1993), na juhu Slovenska Krištín (1996) a na Záhorí Jureček (1996). Uvedená práca Danko et al. (2002) však hovorí o malom počte kvantitatívnych údajov $\mathrm{z}$ hniezdneho obdobia tohto druhu. Statusu a zmenám populácie druhu ako predmetu ochrany na Záhorí sa venujú Gúgh et al. (2015). Z mapovaného územia $\mathrm{v}$ rámci Devínskeho jazera nie sú známe publikované informácie z cieleného monitoringu L. svecica cyanecula, avšak sú k dispozícii priebežne vkladané údaje do databázy AVES Symfony (Jureček R., Danišovičová T., Václav R., Žák M.). Podla údajov v tejto databáze sa mapovaniu avifauny v blízkom transekte $\mathrm{v}$ rokoch 2011-2012 venovali aj J. Svetlík a S. Nuhlíčková.

Ciel'om tejto práce bolo mapovat' v rokoch 2018 a 2020 hniezdiace druhy trstinových spevavcov, viazaných na brehové porasty vymedzeného úseku mŕtveho ramena Šrek. U zistených druhov sme sa zamerali na stanovenie hniezdnych kategórii a vyjadrenie závislosti zistených druhov od environmentálnych faktorov - zložiek biotopu mŕtveho ramena a faktorov počasia.

\section{Metodika a materiál}

\section{Študované druhy}

Trstinové spevavce hniezdia v mokrad'ových biotopoch (trvale alebo periodicky zaplavených) s rôznym rozsahom litorálnej vegetácie, najmä trst'ových, pálkových a ostricových porastov. Často je pre ich hniezdne optimum dôležitý aj výskyt roztrúsených krovín alebo nízkych stromov v podmáčaných makrofytoch.

Kritériovým vtáćím druhom pre CHVÚ Záhorské Pomoravie (SKCHVU016) je slávik modrák (obr. 3) a sú tu známe viaceré jeho hniezdne lokality. Patrí medzi 24 druhov hniezdičov Slovenska, pri ktorých je riziko vyhynutia

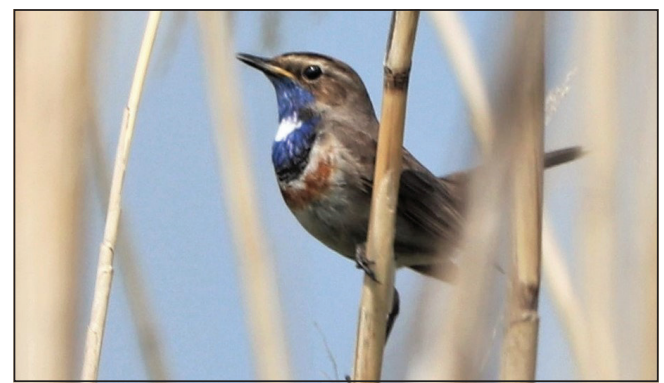

Obr. 3. Samec slávika modráka stredoeurópskeho (Luscinia svecica ssp. cyanecula) (foto M. Mišík).

Fig. 3. Male of the Bluethroat (Luscinia svecica ssp. cyanecula) (photo by M. Mišík, 13. 5. 2020).

v prírode velmi vysoké (druh s početnostou populácie $<2500$ dospelých jedincov) a splńa preto kritérium pre „silne ohrozené druhy“ (Demko et al. 2014). Na južnom Slovensku - Podunajsku, Záhorí, juhu stredného a východného Slovenska, boli potvrdené hniezdenia poddruhu slávik modrák stredoeurópsky (Danko et al. 2002). Gúgh et al. (2015) ho však uvádzajú ako predmet ochrany v CHVÚ Záhorské Pomoravie v dôsledku potvrdenia výskytov v posledných rokoch už len na Záhorí, kde predstavuje hniezdna populácia $100 \%$ slovenskej populácie druhu. Jeho hniezdnym prostredím sú mokrade rôzneho charakteru, predovšetkým mŕtve ramená s dobre vyvinutou litorálnou vegetáciou, $s$ dominantným porastom trsti, ale aj pálky, ostríc a zamokrených vrbín. Velmi dôležitým faktorom pre hniezdne optimum sú mladé stromy a kry (zvyčajne $2-3 \mathrm{~m}$ vysoké), roztrúsené $\mathrm{v}$ podmáčanej vegetácii. $\mathrm{V}$ porovnaní so stavom $\mathrm{v}$ čase navrhovania CHVÚ však Gúgh et al. (2015) konštatujú priaznivé areálové podmienky a pozitívny trend v počte hniezdnych párov. V rámci Záhorského Pomoravia sa Devínske jazero uvádza ako potenciálna hniezdna lokalita (Karaska et al. 2015).

\section{Študované územie}

Približná rozloha mapovaného územia s pril'ahlou lúkou, kde boli sčítané všetky pozorované vtáky, je 75 ha. Územie spadá do geomorfologického celku Borská nížina, pričom vybraná plocha brehových porastov je súčast'ou naj- 


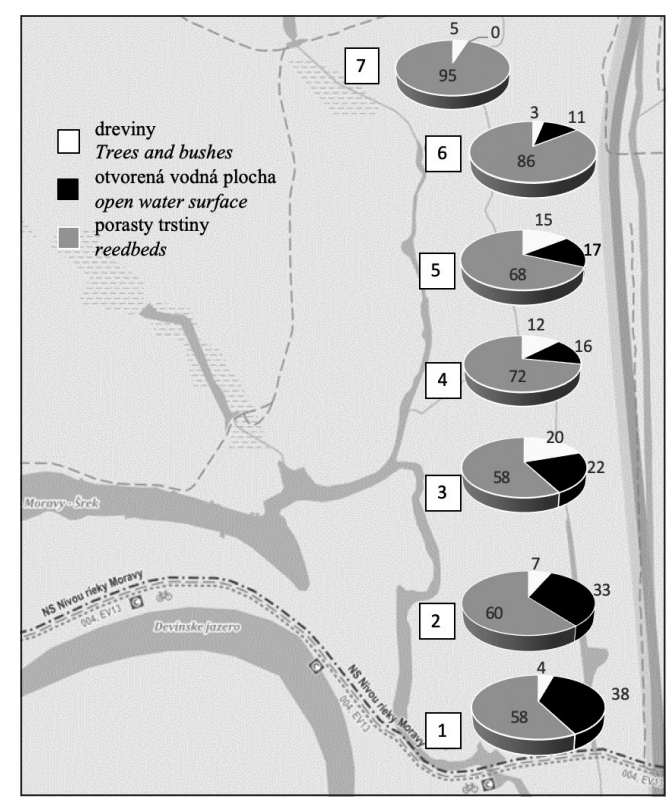

Obr. 4. Rozmiestnenie monitorovacích bodov, s \% prítomných zložiek biotopu.

Fig. 4. Location of monitored points, with the $\%$ of present habitat components.

väčšieho komplexu zachovalých nivných lúk v strednej Európe. Na Devínskom jazere je pestrá mozaika biotopov a územie je zaradené medzi mokrade medzinárodného významu NATURA 2000 (Tomovčík et al. 1999).

Prímestská lokalita Devínske jazero je len niekolko kilometrov vzdialená od západnej časti Bratislavy, pričom predstavuje velmi blízku a dnes už zároveň atraktívnu rekreačnú a prírodnú zónu pre obyvatelov tohto mesta. Ide o územie európskeho významu SKUEV0313 Devínske jazero s celkovou rozlohou 1264,066 ha, ktoré je kvôli zachovalému komplexu mokradí, predstavujúcich najohrozenejšie ekosystémy sveta, súčastou Ramsarskej lokality Niva Moravy. Zároveň spadá pod CHKO Záhorie a CHVÚ Záhorské Pomoravie.

Z lokality Devínske jazero sme vytýčili čast’ mŕtveho ramena Šrek, ktoré predstavuje jednu z biologicky najbohatších častí územia. Jeho brehové porasty s rozlohou 6,38 ha sa nachádzajú v centrálnej časti Ramsarskej lokality Niva Moravy (48¹6'25.22“N; 1657'15.45“E; E483N281, obr. 1, 2). Sledovaný bol 1,2 km dlhý úsek (obr. 4). Sedem bodov bolo rozložených podla modifikovanej metodiky bodového transektu pre sčítanie vtákov (Janda a Řepa 1986), vo vzdialenosti približne $200 \mathrm{~m}$. Cielom bolo zahrnút do transektu dominantné zložky biotopu sledovaného mŕtveho ramena, ich percentuálny podiel je graficky znázornený v turistickej mape (www.mapy.cz).V brehových porastoch ramena je prevládajúca trst’ obyčajná (Phragmites australis) s výskytom vŕb a rôznych druhov krovín (obr. 5a). Ide tak o optimálny biotop pre skúmanú skupinu vtákov, najmä pre slávika modráka (Gúgh et al. 2015). Vodná plocha v meandrujúcich častiach mŕtveho ramena je z velkej časti pokrytá porastom Nymphoides peltata, čím predstavuje pre viacero druhov vodných vtákov miesto vhodné pre získavanie potravy (obr. 5b).

\section{Zber údajov}

Mapovanie hniezdnych teritórií sa robilo od apríla do júla 2018 a 2020. S monitoringom sme začali až v druhej polovici apríla, kedy boli
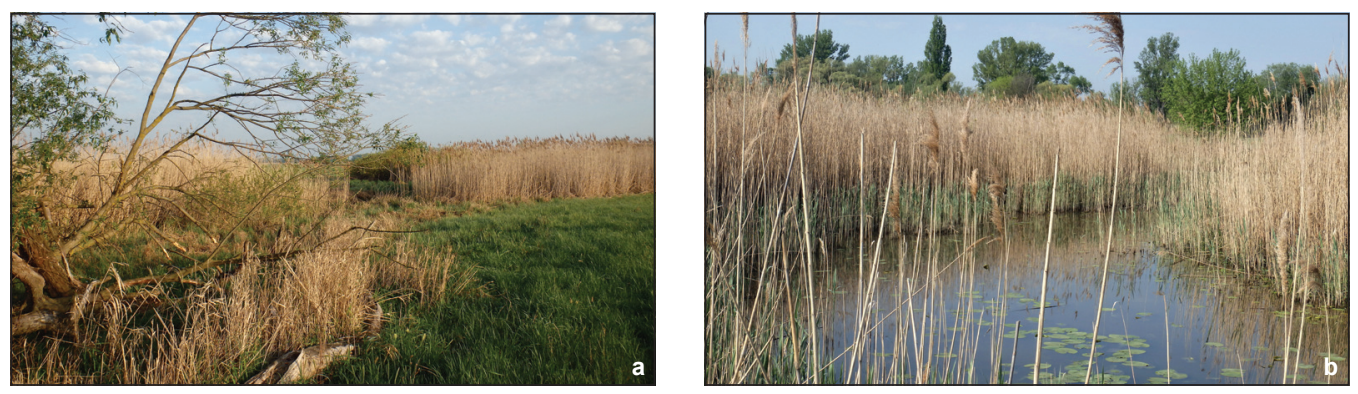

Obr. 5. Hniezdny biotop (a) L. svecica cyanecula, (b) meander ramena Šrek (foto M. Mišík).

Fig. 5. Breeding habitat of (a) L. svecica cyanecula, (b) meander of Šrek oxbow (photo by M. Mišík). 
samce najaktívnejšie a obhajovali svoje teritóriá intenzívnym spevom. Skorší monitoring by nemusel vylúčit' výskyt migrujúcich jedincov a počty hniezdiacich, resp. teritoriálne sa správajúcich jedincov by tak boli skreslené. Pri posune až do začiatku leta bolo možné dokázat' čo najviac hniezdení (vrátane náhradných, druhých hniezdení), najmä na základe pozorovania vylietaných mlád’at. Počas dňa sme sa zamerali na čas najväčšej aktivity od 6:00 do 8:30.

Pri mapovaní sledovaných ornitocenóz boli použité nasledovné metódy:

- metóda bodového transektu u trstinových spevavcov

- mapovanie hniezdnych okrskov slávika modráka (Luscinia svecica)

- dokumentácia s použitím fotopascí

$\mathrm{Na}$ lokalite bolo uskutočnených 6 návštev ročne $\mathrm{v}$ približne dvojtýždňových intervaloch (22. 4. - 24. 6. 2018 a 26. 4. - 2. 7. 2020, pričom dôraz sa kládol na spievajúce samce a na jedince s teritoriálnym správaním.

\section{Mapovanie hniezdnych okrskov} slávika modráka (Luscinia svecica) U slávika modráka bola zist'ovaná aj reakcia na nahrávku spevu, vždy až na konci mapovania, aby neboli výsledky ovplyvnené. Aplikovaná bola modifikovaná metóda bodového transektu pre hniezdiče brehových porastov, pre slávika modráka sme použili metódu hniezdnych okrskov (Janda a Řepa 1986, SOS/BirdLife Slovensko 2013). Na základe takéhoto pozorovania, pravidelne na tom istom mieste (kategória C4 - stály hniezdny okrsok; Ridzoň et al. 2014) možno odvodit' celý pár a predpokladat' tak možné hniezdenie. U slávika modráka sa dali okrsky identifikovat' na základe registrácie súčasne spievajúcich samcov v transekte.

\section{Dokumentácia s použitím fotopascí}

Ako sprievodná metóda mapovania bol okrem fotografického dokumentovania aplikovaný aj monitoring fotopascami. Použité boli 2 fotopasce (model Welltar 7330 MC 940nm a Forestcam LS870 Gen2). Inštalované boli na miestach s rozhraním vodnej plochy a brehu, v bodoch 2 a 6 (obr. 4). Inštalované boli trikrát, s následným zberom: 4. 4./7. 4., 13. 5./25. 5. a 27. 5./9. 6. Vd'aka tejto pomocnej metóde bolo dokázané hniezdenie L. svecica cyanecula, ako aj zdokumentované párenie u druhu E. schoeniclus.

\section{Spracovanie údajov a metodika vyhodnotenia}

Na základe mapových záznamov zistených teritoriálnych prejavov samcov slávika modráka boli lokalizované ich hniezdne okrsky. Podl'a výsledkov metódy bodového transektu bol vyhodnotený celkový počet druhov zistený v študovanej lokalite a denzita hniezdičov vyjadrená ako počet hniezdnych párov na plochu 10 ha v danom území. Hniezdny status (resp. miera preukaznosti hniezdenia na základe správania a záznamov z fotopascí) bol vyhodnotený podl'a medzinárodne schválenej kategorizácie (Ridzoň et al. 2014). Získané kvantitatívne údaje o zaznamenaných trstinových spevavcoch boli graficky interpretované pomocou balíka Excel, Microsoft Office. $\mathrm{Na}$ základe záznamov monitorovaných druhov z fotopascí boli potvrdené hniezdne prejavy navyše aj v miestach a v čase, v akých by bolo vel'mi obtiažne až nemožné tieto druhy sledovat' priamo.

Pomocou mnohorozmernej analýzy a vizualizácie ekologických dát v programe CANOCO 5 (Šmilauer \& Lepš 2014) bola graficky vyobrazená miera vplyvu zvolených environmentálnych faktorov na jednotlivé druhy. Zvolenými habitatovými faktormi boli: percentuálny podiel otvorenej vodnej plochy, trstinového porastu a drevín (kry, stromy) v každom bode transektu. Percentá pokrytia v jednotlivých bodoch boli vypočítané pomocou webovej aplikácie Google Earth. Faktory počasia, reprezentované rozsahom teploty, silou vetra a mierou oblačnosti podla databázy AVES Symfony (http:// aves.vtaky.sk/sk/about/oatlase), boli podla ich rozsahu vyjadrené jedným zo stupňov $1 ; 2 ; 3$; 4. Na vyhodnotenie vztahov medzi šiestimi pozorovanými trstinovými druhmi spevavcov a environmentálnymi faktormi v habitatoch každého zo siedmych bodov transektu bola použitá kanonická korešpondenčná analýza (CCA). Do CCA boli zahrnuté dáta získané z 84 vzoriek (12 
pozorovaní krát 7 bodov transektu) z mŕtveho ramena Šrek. Východiskom pre analýzu bola matica 6 druhov a matica 6 environmentálnych faktorov. Environmentálne faktory predstavovali jednak habitatové parametre - percentuálny podiel otvorenej vodnej plochy, trstinového porastu a drevín (kry, stromy) a tiež faktory počasia - teplota vzduchu, sila vetra a oblačnost'.

$\mathrm{K}$ druhom boli priradené priame počty jedincov, $\mathrm{k}$ trom habitatovým faktorom boli priradené percentuálne pokrytia a $\mathrm{k}$ trom faktorom počasia hodnoty celých čísel od 1 do 4. Kedže u environmentálnych premenných sa ako kvantitatívne údaje použili percentuálne hodnoty a stupne $\mathrm{v}$ celých číslach od 1 do 4 , nejedná sa o rovnakú škálu hodnôt (rádovo odlišné hodnoty). Preto sa pre zhomogenizovanie dát použila transformácia podla odporúčaní pri využití programu CANOCO 5 (Šmilauer a Lepš 2014). Pre percentuálne hodnoty pokrytia habitatov bola vykonaná transformácia pomocou funkcie $\arcsin (\mathrm{X} / 100)$ a pre kategórie 1 až 4 sa použil dekadický logaritmus $\log _{10}(\mathrm{X}+1)$.

\section{Výsledky a diskusia}

Na siedmych bodoch transektu bolo zaznamenaných 6 hniezdiacich druhov spevavcov, viazaných na trstinové spoločenstvá (Acrocephalus schoenobaenus, Emberiza schoeniclus, Locustella luscinioides, Acrocephalus scirpaceus, Acrocephalus arundinaceus, L. svecica cyanecula). Prvé tri druhy početne hniezdili najmä v stanovištiach so zárastom ostríc. Podobné hniezdne nároky potvrdzujú aj údaje na Poiplí (Mojžiš et al.2011). Druh A. arundinaceus spomínajú z Poiplia v súvislosti s rozsiahlymi močiarnymi spoločenstvami trste a pálky. Podobné nároky na hniezdny biotop uvádzajú u druhu A. scirpaceus, avšak s vyhl'adávaním starších a ešte rozsiahlejších močiarnych porastov vysokobylinných spoločenstiev. U L. svecica tam spomínajú iba nehniezdny výskyt. Danko et al. (2002) a Gúgh et al. (2015) však pripisujú tomuto druhu podobné hniezdne nároky ako u spomenutých prvých troch druhov.
Počet hniezdnych okrskov

\section{slávika modráka}

Na základe registrácie spevu sa v bode 5 jednalo o teritóriá dvoch samcov L. svecica cyanecula, zistených pravidelne $\mathrm{v}$ tej istej časti lokality. Okrem trstiny spievali pravidelne v okolí prítomných drevín a mítveho dreva. Jednalo sa teda o úplne ideálny biotop pre daný druh, ked’že preferenciu prítomnosti nízkych stromov a krov uvádzajú aj Gúgh et al. (2015). Druhý samec spieval často $\mathrm{v}$ tom istom čase ako prvý jedinec, v priemere $40 \mathrm{~m}$ od prvého okrsku. Spieval však výhradne vo vrcholkoch trste, vždy zhruba v tých istých miestach. Tento jav sa však po lepšom prieskume teritória dal vysvetlit’ prítomnost'ou malej mokrade a meandra ramena práve bezprostredne pri mieste spevu tohto jedinca. V roku 2020 boli zaznamenané hniezdne okrsky v bodoch 5, 6, a pravdepodobne išlo o hniezdny okrsok aj v bode 7 (obr. 4 a 7). Najmä v bode 6 bolo už od začiatku zrejmé, že miestny samec bude spárený (na základe záznamu samice fotopascou v blízkosti miesta jeho spevu). Jednalo sa taktiež o ideálnu štruktúru biotopu pre daný druh. Trstinový porast s roztrúsenými drobnými vŕbami a krovinami, popadané suché drevá a meander ramena predstavovali vhodné podmienky pre vyhniezdenie, ktoré bolo nakoniec dokázané.

\section{Početnost' trstinových spevavcov na bodovom transekte}

\section{- Luscinia svecica cyanecula}

Početnost' jedincov druhu bola medzi 0 a 3 v oboch rokoch mapovania (obr. 6). Výskyt druhu v bodoch transektu (so stanovením hniezdnych kategórií) v rámci oboch rokov sú zaznačené v 7 bodoch mapovaného transektu (obr. 7).

Dvom spievajúcim samcom $\mathrm{v}$ bode $5 \mathrm{z}$ roku 2018 bola priradená hniezdna kategória B2. Neskôr tu bolo pozorované aj opakované teritoriálne správanie so stálym hniezdnym okrskom (kategória C4). V roku 2020 bolo zaznamenané teritórium na rozhraní bodov 5 a 6 , pričom sa v okolí bodu 5 pohybovalo niekol'ko jedincov 


\section{Luscinia svecica cyanecula}

\section{8}

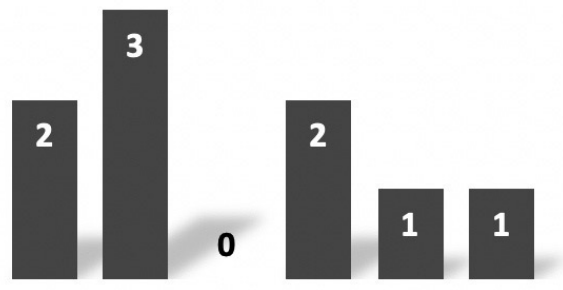

22. 4. 29. 4. 13. 5. 23. 5.10. 6. 24. 6 .
2020

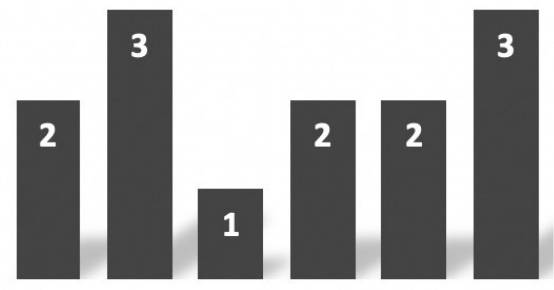

26. 4. 13.5. 27.5. 9.6. 20.6. 2.7.

Obr. 6. Počty jedincov L. svecica cyanecula počas dvanástich kontrol.

Fig. 6. Numbers of L. svecica cyanecula individuals during twelve controls.

(minimálne 2 dospelé samce a jedna samica). V spomínanom teritóriu bol spievajúci samec zaznamenávaný taktiež po celú sezónu (kategória C4), avšak výskyt samice nebol preukázaný. Cielový druh bol v roku 2018 zistený aj na bodoch 1 (29. 4.), 3 (10. 6.) a 7 (23. 5. a 24. 6.), no vždy iba po 1 ex. a len $v$ jednom bode. Najvyšší počet $v$ danom roku bol zaznamenaný 29. 4., kedy v celom transekte spievali 3 samce.

V roku 2020 bola situácia s pohybom jedincov tohto druhu $\mathrm{v}$ rámci jednotlivých bodov transektu podobná. Druh bol zaznamenaný aj v bodoch 2 (dospelá samica, 13. 5.), 4 (spievajúci samec, 20.6.) a 7 (spievajúci samec, 26. 4., 13. 5. a 2. 7.). V bode 7 sa teda taktiež dá hovorit o hniezdnom okrsku adultného samca).

Zaujímavý bol fakt, že samce sa v roku 2018 správali omnoho nápadnejšie a bola zaznamenaná (najmä začiatkom teplej hniezdnej sezóny) silná reakcia na nahrávku. Aj podla Metodiky systematického dlhodobého monitoringu výberových druhov vtákov v CHVÚ (SOS/BirdLife Slovensko 2013) sláviky modráky dobre reagujú na nahrávky hlasu, aj ked's individuálne variabilnou intenzitou reakcie. V roku 2020 spievala väčšina samcov viac z úkrytu a iba málokedy bolo možné ich vyprovokovat' nahrávkou spevu. Tento jav mohol byt' zapríčinený o niečo neskorším príchodom teplého počasia, teda samce boli zaneprázdnenejšie v dôsledku skrátenia času pre prípravu hniezdenia. O niečo vyššie počty a pravidelnejší výskyt mohol byt' dôsledkom vyliatia rieky Morava začiatkom hniezdnej sezóny 2020 (v apríli), čo vytvorilo vel'mi vhodné hniezdne podmienky. V roku 2020 sa fotopascami podarilo v bode 6 pravidelne zaznamenat dva dospelé loviace jedince $(\mathrm{F}+\mathrm{M})$, teda pravdepodobne pár. $\mathrm{V}$ júni tam bolo dokázané aj jeho hniezdenie, fotopasca na záberoch zachytila vylietané mláda (hniezdna kategória D12) a dospelú samicu.

Druh vykazuje na Slovensku mierne pozitívny trend početnosti (Danko et al. 2002).

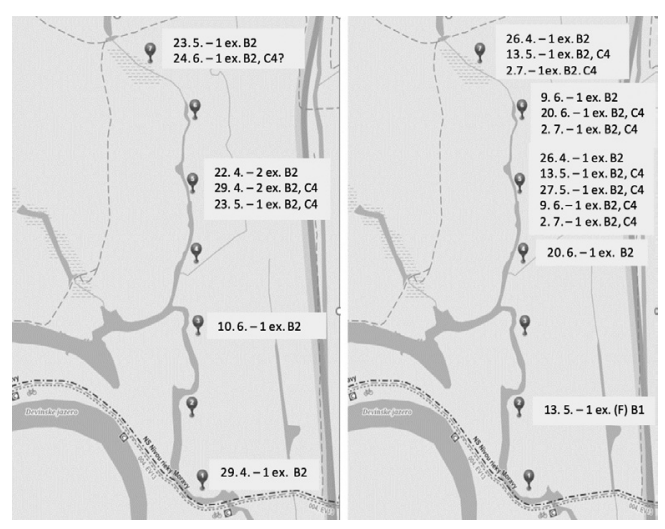

Obr. 7. Výskyt $L$. svecica cyanecula v bodoch transektu a jeho hniezdne kategórie (B1: vhodné prostredie $v$ hniezdnej dobe, B2: spievajúci samec, C4: stály hniezdny okrsok).

Fig. 7. Occurrence of $\mathrm{L}$. svecica cyanecula at the points of the transect and its nesting categories (B1: suitable nesting environment, B2: singing male, C4: permanent breeding territory). 
Fluktuujúci populačný trend sa udáva v oblasti Devínskeho jazera (Karaska et al. 2015). Podla Gúgha et al. (2015) s priaznivým areálovým trendom $v$ rámci celého CHVÚ dokonca rastie počet hniezdiacich párov. Na základe priebežne vkladaných údajov do databázy AVES Symfony (Jureček, Danišovičová, Václav, Žák) je tam zrejmý pravidelný výskyt slávika modráka od r. 2014. Z mapovania pre CHVÚ uvádza Jureček (2017, in verb.) pravdepodobný výskyt asi 6 párov na celom území Devínskeho jazera, pričom nám sa podarilo na sledovanej ploche zistit prítomnost' minimálne troch. Svetlík a Nuhlíčková (2011-2012, in litt.) však v databáze AVES Symfony vo svojich záznamoch zo šiestich mapovaní blízkeho transektu o slávikovi modrákovi žiadne údaje neuvádzajú.

Druh sa v CHVÚ Parížske močiare podla Trnku et al. (2003) vyskytoval v r. 1993 - 2002 ako nepravidelný hniezdič, no v posledných rokoch $\mathrm{z}$ hniezdneho obdobia tu nie sú známe údaje nasvedčujúce hniezdeniu (Trnka in verb.). Kvantitatívnych údajov $\mathrm{z}$ hniezdneho obdobia druhu je podla Danka et al. (2002) vel'mi málo, pričom z Jakubovských rybníkov v CHVÚ Záhorské Pomoravie uvádza hniezdenie Jureček (1996). Báldi $(2004,2006)$ charakterizuje slávika modráka ako výrazného indikátora rozsiahlych
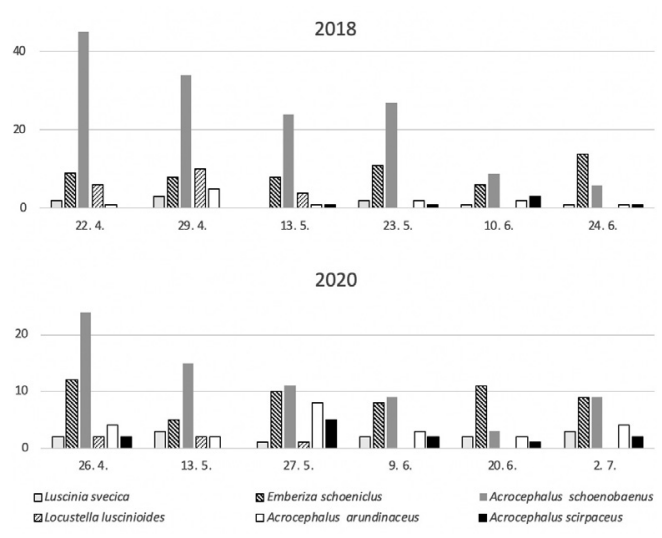

Obr. 8. Počty jedincov trstinových druhov spevavcov v hniezdnych sezónach 2018 a 2020.

Fig. 8. Numbers of reed passerine species in breeding seasons 2018 and 2020. kvalitných trstinových biotopov s krovinatými plochami, v ktorých sa predpokladá hniezdny výskyt aj ostatných trstinových druhov.

\section{- Ostatné druhy trstinových spevavcov}

Najpočetnejším hniezdičom bol v oboch rokoch A. schoenobaenus. Počas prvej kontroly (22. 4. 2018) bolo na celej ploche transektu zistených 46 ex. (obr. 8), pričom išlo takmer výhradne o spievajúce samce (kategória B2). Ostatným jedincom tohto druhu, pozorovaným bez výrazného teritoriálneho správania a bez ohl'adu na pohlavie, možno priradit' hniezdnu kategóriu B1- vhodné prostredie $\mathrm{v}$ hniezdnej dobe, a to aj počas ostatných návštev. V roku 2020 boli na lokalite zaznamenané výrazne nižšie počty tohto druhu. Najvyšší počet spievajúcich samcov v transekte bol počas prvej kontroly (26. 4. 2020) - 24 jedincov s prevahou spievajúcich samcov. Tento jav mohol byt' zapríčinený nízkymi nočnými teplotami na začiatku sezóny.

Druhy $A$. arundinaceus a $A$. scirpaceus boli zistené len $\mathrm{v}$ menších počtoch (do 10 resp. 5 ex. na transekte). Početná bola aj strnádka trstinová (E. schoeniclus), s najvyšším počtom $14 \mathrm{ex}$. 24. 6. 2018, kedy sa jednalo o 7 samcov a 7 samíc/ resp. juv., pričom na niektorých bodoch transektu sa držali v pároch (C3 - pár v hniezdnej dobe). U tohto druhu bolo v oboch rokoch pozorované aj prinášanie potravy (kategória D14).

$\mathrm{V}$ roku 2018 bol pomerne početným druhom L. luscinioides (max. počet 10 spievajúcich samcov - B2, zistený 29. 4. 2018). V roku 2020 bola aj u tohto druhu zaznamenaná výrazne nižšia početnost' na lokalite. Najvyšší počet zistených jedincov uvedeného druhu v transekte bol v danom roku 26. 4. a 13. 5. V oboch prípadoch išlo iba o 2 spievajúce samce. Pokles populácie v lokalite v roku 2020 mohol byt' podobne ako u A. schoenobaenus, následkom nižších teplôt koncom apríla. $\mathrm{V}$ oboch rokoch bol spev druhu L. luscinioides zaznamenávaný len krátku dobu (apríl, máj), pravdepodobne ešte pred spárením (Darolová in litt.).

Druhy Locustella fluviatilis a Locustella naevia boli taktiež zistené $\mathrm{v}$ oboch monitorovacích rokoch, no z hladiska biotopu daných 
druhov ich nemožno zaradit medzi trstinové. Podobným statusom možno označit’ aj Acrocephalus palustris, ktorého typickým biotopom sú bylinné porasty, a preto nie je zaradený do zoznamu cielových druhov, viazaných na trstinové porasty. Uviest' treba aj pozorovanie dalšieho druhu trstinového spevavca, avšak ešte pred začatím monitorovaného hniezdneho obdobia, a to dvoch párov Panurus biarmicus (25. 3. 2018). Počas hniezdneho monitoringu už jeho výskyt registrovaný nebol.

Zistené hniezdiče nachádzali vhodné podmienky v študovanom biotope s prítomnostou depresií s hlbšou vodou, čo potvrdzuje u týchto druhov aj Mérő et al. (2015). Všetky uvádzané trstinové spevavce sa vyskytujú aj v databáze AVES Symfony za posledných 12 rokov.

V oboch rokoch prevládali $A$. schoenobaenus a E. schoeniclus, čo je podobné ako v prácach Tomovčík (1999) a Tomovčík et al. (1999). Avšak L. luscinioides, ktorého autori udávajú ako jeden z dominantných druhov, sme zistili len málo početne. $\mathrm{V}$ druhej polovici oboch hniezdnych období teritoriálna aktivita dokonca absentovala. Naopak u druhu A. arundinaceus, ktorý na hniezdne lokality prilieta o niečo neskôr ako uvádzané tri druhy (Darolová in litt.), bola teritoriálna aktivita zaznamenaná aj koncom hniezdneho obdobia.. Odhadnutá denzita hniezdnych párov trstinových spevavcov na skúmanom území, vid' tab. 1.

V nive Moravy v oblasti Šreku Tomovčík et al. (1999) nezaznamenali slávika modráka, avšak u A. scirpaceus, a A. arundinaceus zistili porovnatel'né údaje ako Jureček (1996) na Jakubovských rybníkoch. Hustota hniezdnych párov u A. schoenobaenus a L. luscinioides korešponduje s údajmi Tomovčíka (1999), ale

Tab. 1. Denzita hniezdnych párov trstinových spevavcov ramena Šrek v rokoch 2018 a 2020 (počet párov/10 ha).

Table 1. Denzity of breeding pairs of the reed passerines in Šrek oxbow in 2018 and 2020 (number of pairs/10 ha).

\begin{tabular}{lcc}
\hline & 2018 & 2020 \\
\hline Luscinia svecica cyanecula & 4,7 & 4,7 \\
Locustella luscinioides & 14,1 & 3,1 \\
Emberiza schoeniclus & 15,7 & 12,5 \\
Acrocephalus arundinaceus & 7,8 & 12,5 \\
Acrocephalus schoenobaenus & 54,9 & 31,3 \\
Acrocephalus scirpaceus & 4,7 & 7,8 \\
\hline
\end{tabular}

u E. schoeniclus a A. scirpaceus zaznamenal pri Šreku podstatne vyššie denzity $(28,6$ a 27,1/10 ha). Naopak pri našich mapovaniach sa vo vyšších počtoch (oproti 2,1 páru/10 ha) vyskytoval druh $A$. arundinaceus.

\section{Závislost' trstinových spevavcov} od zložiek biotopu a faktorov počasia Zvolené environmentálne premenné vysvetl'ujú v dvojrozmernom priestore $16 \%$ celkovej variability druhových dát. Množstvo vysvetlenej variability prvou ordinačnou osou je 8,4 \% (vlastná hodnota prvej osi $\mathrm{F}_{1}=0,0984$ ) a druhou ordinačnou osou je 7,5 \% (vlastná hodnota druhej osi $\mathrm{F}_{2}=0,0882$ ). Množstvo vysvetlenej variability prvými dvomi osami vzhl'adom na množstvo variability vysvetlenej všetkými zvolenými environmentálnymi dátami je 85,5 \%. Rozmiestnenie jednotlivých druhov na ordinačnom diagrame naznačuje ich nároky na prostredie (obr. 9). U niekol'kých druhov bola zaznamenaná výrazná viazanost' na jednotlivé zložky biotopu v bodoch transektu. Počas monitoringu prevládali zväčša priaznivé podmienky a kvôli zaznamenávaniu hlasových prejavov moni-

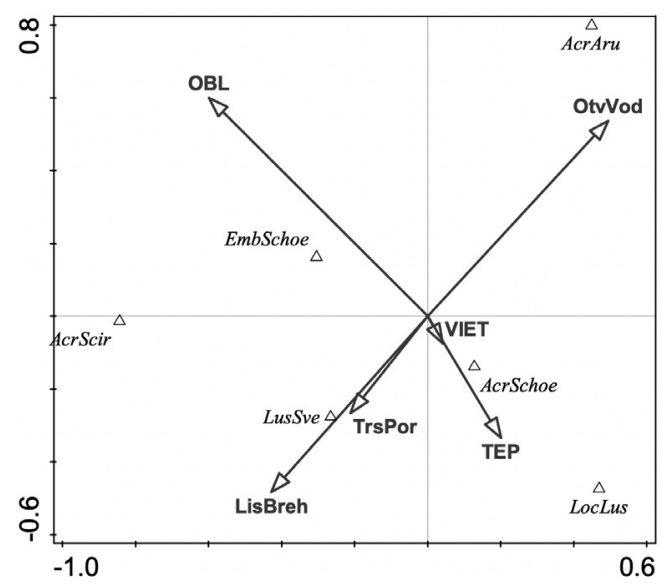

Obr. 9. Ordinačný diagram CCA analýzy - rozmiestnenie trstinových druhov spevavcov a environmentálnych premenných. (OBL - oblačnost', VIET - vietor, TEP - teplota, OtvVod - otvorená vodná plocha, TrsPor - trstinové porasty, LisBreh - dreviny).

Fig. 9. Ordination diagram of CCA analysis - distribution of reed passerine species and environmental variables. (OBL - clouds, VIET - wind, TEP - temperature, OtvVod - open water surface, TrsPor-reedbeds, LisBreh - trees and bush). 
torovaných spevavcov sme sa snažili vyhnút' veterným ránam. Preto faktor vetra nezohrával významnú úlohu v aktivite miestnej populácie trstinových druhov spevavcov (reprezentovaný krátkym vektorom). Najvýraznejšie sa viazanost' na habitat prejavila u $A$. arundinaceus a L. svecica cyanecula, ktoré z tohto hl'adiska vykazovali antagonistické nároky. U prvého spomínaného druhu bola zjavná vysoká afinita k otvorenej vodnej ploche. Jeho pravidelný výskyt bol zaznamenávaný iba v bode 1 a čiastočne v bode 2 , teda na začiatku transektu, kde je najväčší podiel otvorenej vodnej plochy (obr. 4). Druh inklinuje k habitatom s vyššími a hrubšími steblami trstiny s fluktuujúcou vodnou hladinou, čo sa prejavilo aj takmer dvojnásobným počtom spievajúcich samcov vo vlhšom roku 2020 (tab. 1). Takéto výsledky potvrdzujú aj zistenia Poulina et al. (2002). Ordinačná analýza zobrazuje optimum L. svecica cyanecula $\mathrm{v}$ bodoch s trstinovým porastom, a navyše dokazuje jeho silné inklinovanie k drevinovým brehovým porastom. Napriek výskytu L. luscinioides len v prvej polovici oboch hniezdnych období, sme zaznamenali jeho výrazne vyššie počty $(6 / 10 / 4$ ex.) pri vyšších ranných teplotách (často nad $20^{\circ} \mathrm{C}$ ) v r. 2018 (obr. 8). Podstatne chladnejšie rána v r. 2020 (okolo $10^{\circ} \mathrm{C}$ ) spôsobili výrazný pokles jeho spevnej aktivity (2/2/1 ex.). V sledovanom úseku ramena Šrek. Práve $\mathrm{z}$ tohto dôvodu bola teplota znázornená ako vplyvný ukazovatel' u tohto druhu. Podobnú závislost' na teplote vzduchu vidiet' aj u A. schoenobaenus (obr. 9), ktorého výskyt bol zaznamenaný približne v dvojnásobných počtoch počas teplej jari 2018 oproti roku 2020, s chladnejším hniezdnym obdobím. Umiestnenie tohto druhu v blízkosti stredu ordinačného diagramu, kde sú hodnoty všetkých premenných priemerné, však znázorňuje jeho pravidelný výskyt v takmer všetkých typoch sledovaného prostredia a zároveň $\mathrm{v}$ pomerne početných množstvách (obr. 8). Čiastočne to možno povedat' aj o druhu E. schoeniclus, ale s výskytom v nižších počtoch, u ktorého sa oblačnost' ukázala ako vplyvný faktor na jeho aktivitu. Fakt, že E. schoeniclus nevykazuje výrazné preferencie, opisuje aj Báldi (2004, 2006). Ako najmenej závislý na študovaných faktoroch sa graficky ukázal druh $A$. scirpaceus, u ktorého aj Poulin et al. (2002) konštatujú nezávislé osídlenie rôznych typov trstinových habitatov.

\section{Záver}

Na základe získaných výsledkov boli najefektívnejšie v oboch rokoch prvé dve návštevy v druhej dekáde apríla resp. začiatkom mája s najvyšším počtom spievajúcich samcov u takmer všetkých trstinových spevavcov. U slávika modráka samce už neskôr počas hniezdenia neboli tak nápadné a spievali iba sporadicky. Po vyhniezdení začali opät' obhajovat' teritóriá intenzívnejšie, no spev nebol tak výrazný ako začiatkom hniezdnej sezóny. Silná závislost' od zložiek biotopu sa prejavila zvlášt' u druhov L. svecica cyanecula a A. arundinaceus. Ako optimálny hniezdny biotop prvého spomínaného druhu sa potvrdili trstinové porasty s vysokým podielom drevín (kry, stromy, mŕtve drevo). Druh $A$. arundinaceus pre hniezdenie uprednostňoval stanovištia s otvorenou vodnou plochou. Počas dvojročného štúdia boli zistené údaje o druhovom zložení a početnosti prítomných trstinových druhov spevavcov, ktorých biotopy sú v súvislosti s ubúdaním depresií a mokradí na Slovensku ohrozené. Pozitívne bolo preto dokázané hniezdenie šiestich druhov trstinových spevavcov, a zvlášt' kritériového, ohrozeného druhu slávika modráka stredoeurópskeho. $\mathrm{Na}$ udržiavanie vhodných podmienok pre výskyt a hniezdenie predmetnej skupiny vtákov je potrebné zachovat' a chránit' výnimočnú prírodnú nivu Moravy spolu s prirodzeným vodným režimom toku. Existujúce prepojenie hlavného koryta so záplavovým územím rieky Moravy zaist'uje totiž dostatočnú vlhkost' v blízkych trstinových porastoch Devínskeho jazera. Pri dôslednej ochrane a pravidelnom monitorovaní lokality by navyše bolo pravdepodobne možné dosledovat' a potvrdit' výskyt a predpokladané hniezdenie druhu Panurus biarmicus. 


\section{Pod'akovanie}

Monitorovanie bolo v roku 2020 finančne podporené v rámci Malého členského projektu SOS BirdLife Slovensko, fotopasce boli zakúpené z finančného príspevku udeleného z grantu stredoeurópskej nadácie „Talenty Novej Európy 2019“. Naša vd’aka patrí Mgr. S. Nuhlíčkovej, PhD. a Mgr. R. Jurečkovi za cenné odborné rady, a tiež recenzentom za odborné pripomienky a korekcie.

\section{Literatúra}

BÁLDI A. 2004: Area requirements of passerine birds in the reed archipelago of Lake Velence, Hungary. —Acta Zoologica Academiae Scientiarum Hungaricae 50: 1-8.

BÁLDI A. 2006: Factors influencing occurence of passerines in the reed archipelago of Lake Velence (Hungary). Acta Ornithologica. 41: 1-6.

DAnko Š., DARolová A. \& KrišTín A. (eds.). 2002: Rozšírenie vtákov na Slovensku. - VEDA, Bratislava.

Demko M., Krištín A. \& PAČenovský S. 2014: Červený zoznam vtákov Slovenska. - Slovenská ornitologická spoločnost'/BirdLife Slovensko, Bratislava.

Gúgh J., Trnka A., Karaska D. \& RidzoŇ J. 2015: Zásady ochrany európsky významných druhov vtákov a ich biotopov. - Štátna ochrana prírody SR, Banská Bystrica.

Hoi H. (ed). 2001: The ecology of reed birds. - Austrian Academy of Sciences, Wien.

JANDA J. \& ŘEPA P. 1986: Metody kvantitatívního výzkumu v ornitologii. - Státné zemědělské nakladatelství, Praha.

JUREČEK R. 1996: Ornitocenózy rybníkov v okolí Malaciek, Diplomová práca. - Prírodovedecká fakulta UK, Bratislava.

Karaska D., Trnka A., Krištín A. \& Ridzoň, J. 2015: Chránené vtáčie územia Slovenska. —Štátna ochrana prírody SR, Banská Bystrica.

Kloubec B. \& ČAPEK M. 1993: Doterajšie výsledky výskumu avifauny Parížskych močiarov. - Zprávy MOS 51: 55-69.

KRIŠTín A. 1996: Ornitocenózy vodnej nádrže Ružiná a potravné zoskupenia vtákov v zimnom období. Tichodroma 9: 5-30.

KRIŠTín A. 2002: Hlavné skupiny biotopov Slovenska z hladiska vtáctva. - Pp: 17-21. In: DANko Š., DARolová A. \& KRIŠTín A. (eds.): Rozšírenie vtákov na Slovensku. - VEDA, Bratislava.
Leisler B., Ley H. W., Winkler H. 1989: Habitat, behavior and morphology of Acrocephalus warblers - an integrated analysis. - Ornis Scandinavica 20: $181-186$

Mérő T. O., Lontay L. \& Lengyel Sz. 2015: Habitat management varying in space and time: the effects of grazing and fire management on marshland birds. - Journal of Ornithology 156, 3: 579-590.

MojŽIš M., Kerestúr D., VÁclav R. \& KrišTín A. 2011: Vtáctvo Chráneného vtáčieho územia Poiplie. - Slovenská ornitologická spoločnosṫ/BirdLife Slovensko, Ústav zoológie SAV, Bratislava.

Paracuellos M. 2006: Relationships of songbird occupation with habitat configuration and bird abundance in patchy reed beds. - Ardea 94: 87-98.

Poulin B., Lefebvre G. \& Mauchamp A. 2002: Habitat requirements of passerines and reedbed management in southern France. - Biological conservation 107: 315-325.

Ridzoň J., Topercer J., Krištín A., Chavko J., Karaska D. \& KoRŇAn M. 2014: Atlas vtákov Slovenska 2014-2018, metodická príručka. — Slovenská ornitologická spoločnost' /BirdLife Slovensko, Bratislava.

SLOVENSKÁ ORNITOLOGICKÁ SPOLOČNOSŤ /BIRDLIFE SLOvensko. 2013: Metodika systematického dlhodobého monitoringu výberových druhov vtákov v chránených vtáčích územiach. - Štátna ochrana prírody SR, Banská Bystrica.

Šmilauer P. \& LePš J. 2014: Multivariate Analysis of Ecological Data using Canoco 5. - Cambridge University Press.

Toмоvčíк M. 1999: The annual dynamics of the bird communities inhabiting the Morava River floodplain biotops. Reedbeds. — Biológia (Bratislava) 54: 195-205.

Tomovčík M., Darolová A., Kürthy A., Vongrej S., Cнаvко J. \& NogA M. 1999: Ekologické vztahy vtákov k biotopu aluviálnych lúk. - Pp: 161-183. In: ŠEFFER J. \& STANová V. (eds.): Aluviálne lúky rieky Moravy význam obnova a manažment. — Daphne, Bratislava.

TrNkA A. 2005: Lokálne pohyby a denné teritóriá trstových druhov spevavcov v pohniezdnom období. - Sylvia 41:94-102.

Trnka A., ČapeK M. \& Kloubec B. 2003: Vtáky národnej prírodnej rezervácie Parížske močiare. - VEDA, Bratislava.

TrNkA A. \& HRdLovič F. 2007: CES program v NPR Parížske močiare - výsledky po prvom roku. - Pp: 29-30. 
In: Kropil R. \& LeŠo P. (eds.): Aplikovaná ornitológia. Technická univerzita, Zvolen.

Trnka A., Literák I., Sychra O. \& Podzemný P. 2008: Jarný odchyt vtákov v Národnej prírodnej rezervácii Parížske močiare (JZ Slovensko). - Tichodroma 20: 137-139.

ZANETTE, L. 2000: Fragment size and the demography of an area-sensitive songbird. - Journal of Animal Ecology 69: 458-470.
Zuna-Kratky T. , Kalivodová E., Kürthy A., Horal D. \& HorÁk P. 2000: Die Vögel der March-Thaya-Auen im österreichisch-slowakisch-tschechischen Grenzraum. - Distelverein, Deutsch-Wagram.

Received: 23. 11. 2020

Accepted: 29. 1. 2020

Online: 28. 2. 2021 